\title{
GALLOTANNIN AND FLAVONOID GLYCOSIDES FROM THE STEM BARK OF ACER NEGUNDO (L.)
}

\author{
Enaam Y. Backheet
}

Department of Pharmacognosy, Faculty of Pharmacy, Assiut University, Assiut, Egypt

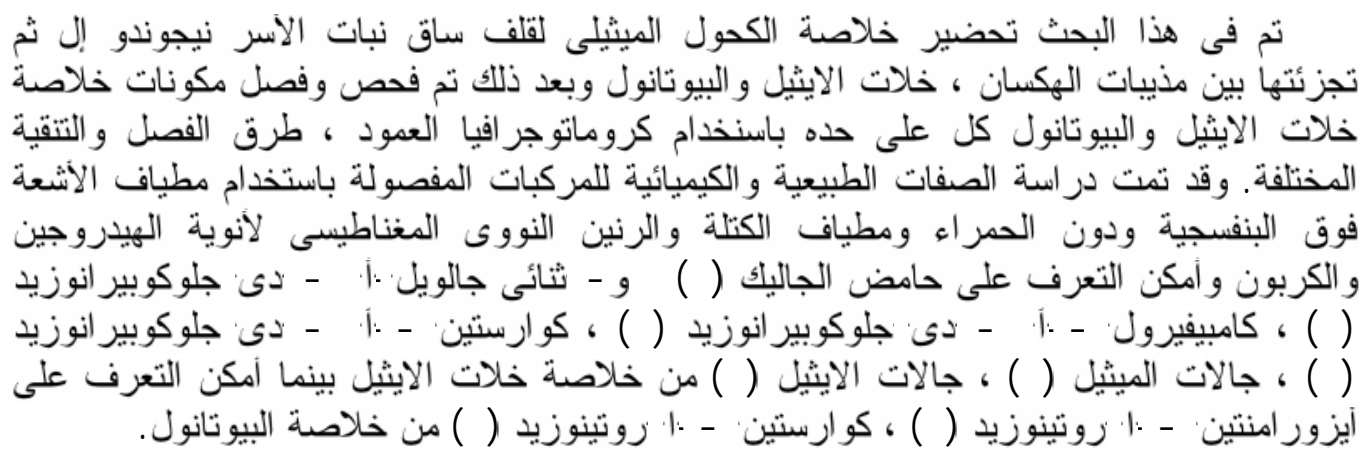

Gallic acid (1), 1,2-di-O-galloyl- $\beta$-D-glucopyranoside (2), kaempferol-3-O- $\beta$-Dglucopyranoside (3), quercetin-3-O- $\beta$-D-glucopyranoside (4) methyl gallate (5), ethyl gallate (6), isorhamnetin-3-O-rutinoside (7) and quercetin-3-O-rutinoside (8) were isolated for the first time from the methanolic extract of the stem bark of Acer negundo (L.). Identification of these compounds has been established by physical, chemical and spectral evidence (UV, IR, FAB-MS, ${ }^{1} \mathrm{H}$ - and $\left.{ }^{13} \mathrm{C}-\mathrm{NMR}\right)$.

\section{INTRODUCTION}

Acer negundo (L.), Boxelder, Ash-leaved Maple $^{1}$ (Maple Family, ${ }^{2}$ Aceraceae) is a tree that may reach about 1.5-2.0 meter in height. The leaves are opposite, pinnately compound, 3 to 5 (7 to 9) leaflets, ovate to oblonglanceolate, coarsely serrate or terminal one lobed and their colour is bright green above, glabrous and lighter green beneath. ${ }^{1}$ The flowers are dioecious, yellowish green. The fruit is samara, matures in September to October. ${ }^{1}$ The genus Acer is cultivated for ornamental purposes. ${ }^{2}$ The bark is prescribed as an astringent, for hepatic disorders and as eye wash. $^{3,4}$

Several constituents have been isolated from plants of genus Acer such as anthocyanins, diacylated anthocyanins, galloylglucoside, galloylcyanidin glycosides, ${ }^{5,6}$ phenolic hydrolysable tannins (1-O-galloyl- $\alpha$ L-rhamnose, 1-O-galloyl- $\beta$-D-glucose $){ }^{7}$ diarylheptanoid acerogenin A-E, their glycosides as well as B-orcinol derivatives. ${ }^{4,8,9}$ Flavonoids myricetin, luteolin glucosides, kaempferol, quercetin, acylated flavonols and biflavonoids were isolated from the leaves of different Acer species. ${ }^{10-14}$

In this study, we report the isolation and identification of gallotannin and flavonoid glycosides from the stem bark of the titled plant.

\section{EXPERIMENTAL}

\section{General experimental procedures}

1- Melting points are uncorrected and were determined by Stuart Scientific melting point SMP1 instrument (England).

2- UV spectra are measured in methanol using an Uvidec-320 (Jasco, Tokyo, Japan) spectrophotometer with matched $1 \mathrm{~cm}$ quartz cells.

3- ${ }^{1} \mathrm{H}$ - and ${ }^{13} \mathrm{C}-\mathrm{NMR}$ spectra were measured in $\mathrm{DMSO}-d_{6}$ and $\mathrm{CD}_{3} \mathrm{OD}$ at $500 \mathrm{MHz}$ by Bruker Avance spectrometer, at $400 \mathrm{MHz}$ by JEOL TNM-LA400, FT NMR system, at $300 \mathrm{MHz}$ by XL-300 Varian (Germany) and JEOL JNM-EX300 spectrometers (Japan) using TMS as internal standard. 
4- FAB-MS was measured by JEOL, JMS 600 H (Japan).

5- UV-lamp (254, $366 \mathrm{~nm})$ VI, 6 LC Marine Lavalee-Cedex France.

6- Column chromatography was performed with silica gel (E. Merck, Germany), Develosil Lop ODS (30-50 $\mu$, Nomura chemicals) and sephadex LH-20 (Pharmacia Biotech., AB, Upsala, Sweden).

7- TLC was performed with precoated silica gel $60 \mathrm{~F}_{254}$, and RP-18 $\mathrm{F}_{254}$ (E. Merck, Germany).

8- Authentic samples were obtained from Department of Pharmacognosy, Faculty of Pharmacy, Assiut University.

9- Visualization:

Spots were visualized under UV and by spraying with $2.0 \%$ ferric chloride solution.

10- Solvent systems:

Solvent systems used for silica gel TLC screening:

I- Chloroform - methanol (90:10)

II- Chloroform - methanol - water (65:30:5)

III- Chloroform - methanol - water (75:22:3)

IV-n-Butanol - acetone - formic acid - water (60:17:8:15)

Solvent systems used for RP-18 TLC:

I- Water - methanol (40:10)

II- Water - methanol (30:20)

\section{Plant material}

The stem bark of Acer negundo (L.) was collected from the Faculty of Agriculture, Assiut University in May 2001 and identified by Prof. Dr. Gamal Taha, Department of Horticulture, Faculty of Agriculture, Assiut University.

\section{Extraction and isolation}

The air-dried powdered stem bark (1.5 $\mathrm{Kg}$ ) of Acer negundo (L.) was extracted with methanol (5 liters) at room temperature by maceration and concentrated under vaccum. The concentrated extract (130 g) was diluted with distilled water and then subjected to solvent fractionation with $\mathrm{n}$-hexane $(4 \times 500$ $\mathrm{ml})$, ethyl acetate $(5 \times 500 \mathrm{ml})$ and n-butanol $(3 \times 500 \mathrm{ml})$. The obtained fractions were separately concentrated under vaccum to solvent free residue $(30,60$ and $30 \mathrm{~g}$ respectively) and examined for different constituents by silica gel TLC (systems I and II).

\section{Isolation}

\section{A- Ethyl acetate fraction}

About $10 \mathrm{~g}$ of ethyl acetate soluble fraction was chromatographed on silica gel column $(300 \mathrm{~g}, 5 \times 120 \mathrm{~cm})$. Elution was started with chloroform followed by chloroformmethanol gradient. Fractions of $250 \mathrm{ml}$ were collected, they are monitored by TLC and similar fractions were combined together. Fractions eluted with chloroform-methanol (80:20) were concentrated under vaccum (4.0 $\mathrm{g}$ ), rechromatographed on ODS column (400 g, $5 \times 120 \mathrm{~cm})$ and eluted with methanol-water (10:20) to afford fractions I, II, III, it was then eluted with methanol-water (10:10) to afford fraction IV. Fraction I was rechromatographed on ODS column, it was eluted with methanolwater (10:40) to afford compound 1. Repeated purification of fraction II on sephadex LH-20 and then on ODS column, eluted with methanol- water (10:20 and 10:10) yielded compound 2. Fraction III was rechromatographed on sephadex LH-20 eluted with methanol to give compounds 3 and $\mathbf{4}$. By repeated purification of fraction VI on sephadex LH-20 and then on ODS column, eluted with methanol-water (10:10), it yielded compounds 5 and $\mathbf{6}$.

\section{B- n-Butanol fraction}

About $5 \mathrm{~g}$ of $\mathrm{n}$-butanol soluble fraction was chromatographed on silica gel column (150 g, $5 \times 120 \mathrm{~cm})$. Elution started with ethyl acetate followed by ethyl acetate-methanol gradient. Fractions of $200 \mathrm{ml}$ were collected and screened by TLC. Fractions eluted with ethyl acetate-methanol (80:20) were rechromatographed on sephadex LH-20 column with methanol to afford compounds $\mathbf{7}$ and $\mathbf{8}$ which were then purified by preparative silica gel plates $60 \mathrm{~F}_{254}$ and solvent system II.

\section{Acid hydrolysis}

Five-mg portion of each of the isolated glycosides was dissolved in $5 \mathrm{ml}$ methanol to which $5 \mathrm{ml}$ of $5 \%$ hydrochloric acid is added. The mixture was refluxed for 3 hours on a boiling water-bath, then cooled. The aglycone was extracted with chloroform, purified and subjected to TLC. The produced sugars were identified on silica gel TLC with solvent system IV. 
Gallic acid (1): White crystalline needles [methanol], m.p 250-252 $,(200 \mathrm{mg}), \mathrm{R}_{\mathrm{f}}=0.25$ (system III), IR, v, $\mathrm{cm}^{-1}$ (KBr disc), 3400, 1694, 1615 .

1,2-Di-O-galloyl- $\beta$-D-glucopyranoside (2): Colourless needles [methanol], $(50 \mathrm{mg}), \mathrm{m} . \mathrm{p}$ $168-170^{\circ}, \mathrm{R}_{\mathrm{f}}=0.19$ (system III), FAB-MS: at $m / z: 485$ for $\mathrm{C}_{20} \mathrm{H}_{20} \mathrm{O}_{14}$. ${ }^{1} \mathrm{H}-\mathrm{NMR}$ spectrum (300 MHz, $\left.\mathrm{CD}_{3} \mathrm{OD}\right)$ : $\delta$ 3.09-4.40 (m, sugar protons), $6.04\left(1 \mathrm{H}, \mathrm{d}, \mathrm{J}=7.50 \mathrm{~Hz}, \mathrm{H}-1^{\prime}\right), 5.25$ $\left(1 \mathrm{H}, \mathrm{t}, \mathrm{J}=7.50 \mathrm{~Hz}, \mathrm{H}-2^{\prime}\right), 7.12(4 \mathrm{H}, \mathrm{s}$, galloyl$\mathrm{H}),{ }^{13} \mathrm{C}-\mathrm{NMR}$ spectrum (75 $\left.\mathrm{MHz}, \mathrm{CD}_{3} \mathrm{OD}\right)$ : Table 1.

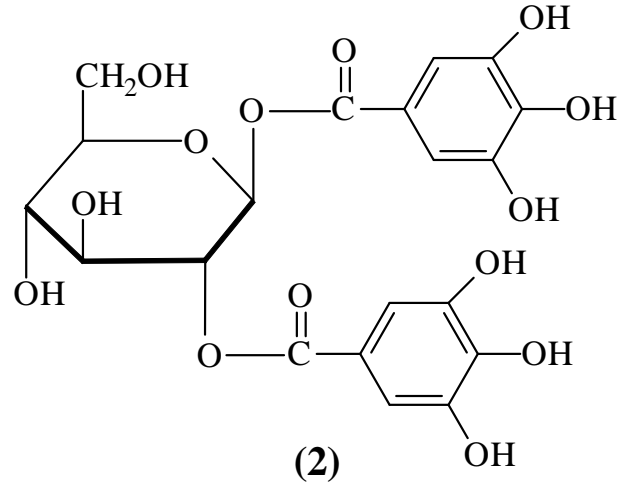

Table 1: ${ }^{13} \mathrm{C}-\mathrm{NMR}$ data of compounds ( 2 and $\mathbf{6}$ ).

\begin{tabular}{|c|c|c|}
\hline Group & 2 & 6 \\
\hline Galloyl CO & 168.66 & 168.10 \\
& 170.05 & \\
\hline Galloyl C-1 & 120.00 & 121.50 \\
& 120.15 & \\
\hline Galloyl C-2,6 & 109.85 & 109.70 \\
& 110.10 & \\
\hline Galloyl C-3,5 & 143.05 & 146.10 \\
& 143.05 & \\
\hline Galloyl C-4 & 139.80 & 139.30 \\
& 139.59 & \\
\hline $\mathrm{CH}_{2}$ & ------ & 61.31 \\
\hline $\mathrm{CH}_{3}$ & ------ & 14.30 \\
\hline Sugar moiety & & \\
$1^{\prime}$ & 92.30 & \\
$2^{`}$ & 74.24 & \\
$3^{`}$ & 75.44 & \\
$4^{`}$ & 70.17 & \\
$6^{`}$ & 77.89 & \\
\hline
\end{tabular}

Spectra were measured by $75 \mathrm{MHz}$ (2), $125 \mathrm{MHz}$ (6) in $\mathrm{CD}_{3} \mathrm{OD}$, relative to TMS).
Kaempferol-3-O- $\beta$-D-glucopyranoside (3): Yellow amorphous powder $(300 \mathrm{mg}), \mathrm{R}_{\mathrm{f}}=0.71$ (system II), UV ( $\left.\lambda_{\max } \mathrm{nm}\right) \mathrm{MeOH}$ : 265, 300sh, 350, NaOMe: 273, 325sh, 404, $\mathrm{AlCl}_{3}: 275$, 302sh, 347, 400, $\mathrm{AlCl}_{3} / \mathrm{HCl}: 275,348,403$, NaOAc: 273, 371, $\mathrm{NaOAc} / \mathrm{H}_{3} \mathrm{BO}_{3}: 265,351$. ${ }^{1} \mathrm{H}-\mathrm{NMR}$ spectrum $\left(300 \mathrm{MHz}, \mathrm{DMSO}-d_{6}\right): \delta$ 3.09-3.66 (m, sugar protons), $5.46(1 \mathrm{H}, \mathrm{d}, \mathrm{J}=$ $\left.6.9 \mathrm{~Hz}, \mathrm{H}-1^{\prime \prime}\right), 6.20(1 \mathrm{H}, \mathrm{d}, \mathrm{J}=1.80 \mathrm{~Hz}, \mathrm{H}-6)$, $6.42(1 \mathrm{H}, \mathrm{d}, \mathrm{J}=1.80 \mathrm{~Hz}, \mathrm{H}-8), 6.88(2 \mathrm{H}, \mathrm{d}, \mathrm{J}=$ $\left.9.00 \mathrm{~Hz}, \mathrm{H}-3^{\prime}, 5^{\prime}\right), 8.04(2 \mathrm{H}, \mathrm{d}, \mathrm{J}=9.00 \mathrm{~Hz}, \mathrm{H}-$ $\left.2^{\prime}, 6^{\prime}\right),{ }^{13} \mathrm{C}-\mathrm{NMR}$ spectrum (75 MHz, DMSO$\left.d_{6}\right)$ : Table 2.<smiles>[R20]Oc1cc(O)c2c(=O)c(O[R20])c(-c3ccc(O)c([R3])c3)oc2c1</smiles>

$\begin{array}{clcc}\text { Compound } & \mathrm{R}_{1} & \mathrm{R}_{2} & \mathrm{R}_{3} \\ & & & \\ \mathbf{3} & \text { glucose } & \mathrm{H} & \mathrm{H} \\ \mathbf{4} & \text { glucose } & \mathrm{H} & \mathrm{OH} \\ \mathbf{7} & \text { glucose-rhamnos } & \mathrm{H} & \mathrm{OMe} \\ \mathbf{8} & \text { glucose-rhamnose } & \mathrm{H} & \mathrm{OH}\end{array}$

Quercetin-3-O- $\beta$-D-glucopyranoside (4): Yellow amorphous powder $(350 \mathrm{mg}), \mathrm{R}_{\mathrm{f}}=0.55$ (system II), UV ( $\left.\lambda_{\max } \mathrm{nm}\right) \mathrm{MeOH}: 257,269 \mathrm{sh}$, 362, NaOMe: 272, 324sh, 410, $\mathrm{AlCl}_{3}: 273$, 305, 437, $\mathrm{AlCl}_{3} / \mathrm{HCl}: 273,348,405, \mathrm{NaOAc}$ : 274, 324, 375, $\mathrm{NaOAc} / \mathrm{H}_{3} \mathrm{BO}_{3}: 265,298,377$. ${ }^{1} \mathrm{H}-\mathrm{NMR}$ spectrum $\left(300 \mathrm{MHz}, \mathrm{DMSO}-d_{6}\right): \delta$ 3.09-3.63 $(\mathrm{m}$, sugar protons $), 5.46(1 \mathrm{H}, \mathrm{d}, \mathrm{J}=$ $\left.7.2 \mathrm{~Hz}, \mathrm{H}-1^{\prime \prime}\right), 6.18(1 \mathrm{H}, \mathrm{d}, \mathrm{J}=1.80 \mathrm{~Hz}, \mathrm{H}-6)$, $6.39(1 \mathrm{H}, \mathrm{d}, \mathrm{J}=1.80 \mathrm{~Hz}, \mathrm{H}-8), 6.83(1 \mathrm{H}, \mathrm{d}, \mathrm{J}=$ $\left.9.00 \mathrm{~Hz}, \mathrm{H}-5^{\prime}\right), 7.51\left(1 \mathrm{H}, \mathrm{d}, \mathrm{J}=2.40 \mathrm{~Hz}, \mathrm{H}-2^{\prime}\right)$, $7.65\left(1 \mathrm{H}, \mathrm{dd}, \mathrm{J}=2.40,9.00 \mathrm{~Hz}, \mathrm{H}-6^{\prime}\right), 12.63$ $(1 \mathrm{H}, \mathrm{s}, 5-\mathrm{OH}),{ }^{13} \mathrm{C}-\mathrm{NMR}$ spectrum $(75 \mathrm{MHz}$, DMSO- $\left.d_{6}\right)$ : Table 2.

Methyl gallate (5): White amorphous powder $(50 \mathrm{mg}), \mathrm{R}_{\mathrm{f}}=0.38$ (system III). ${ }^{1} \mathrm{H}-\mathrm{NMR}$ spectrum $\left(500 \mathrm{MHz}, \mathrm{CD}_{3} \mathrm{OD}\right): \delta 7.20(2 \mathrm{H}, \mathrm{s}, \mathrm{H}-$ $2,6)$ and $3.85\left(3 \mathrm{H}, \mathrm{s}, \mathrm{OCH}_{3}\right)$.

Ethyl gallate (6): White powder (100 mg), $\mathrm{R}_{\mathrm{f}}$ $=0.44$ (system III). ${ }^{1} \mathrm{H}-\mathrm{NMR}$ spectrum $(500$ $\left.\mathrm{MHz}, \mathrm{CD}_{3} \mathrm{OD}\right): \delta 7.03(2 \mathrm{H}, \mathrm{s}, \mathrm{H}-2,6), 4.25(2 \mathrm{H}$, $\left.\mathrm{q}, \mathrm{CH}_{2} \mathrm{CH}_{3}\right)$ and $1.32\left(3 \mathrm{H}, \mathrm{t}, \mathrm{CH}_{2} \mathrm{CH}_{3}\right) .{ }^{13} \mathrm{C}-$ NMR spectrum (125 MHz, $\left.\mathrm{CD}_{3} \mathrm{OD}\right)$ : Table 1. 
Table 2: ${ }^{13} \mathrm{C}$-NMR data of compounds $(3,4$ and 8 ).

\begin{tabular}{|c|c|c|c|}
\hline C-Atoms & $3^{*}$ & $4^{*}$ & $8^{* *}$ \\
\hline 1 & ----- & ----- & ----- \\
\hline 2 & 156.19 & 156.16 & 156.17 \\
\hline 3 & 133.15 & 133.31 & 136.09 \\
\hline 4 & 177.42 & 177.44 & 178.71 \\
\hline 5 & 161.20 & 161.25 & 161.99 \\
\hline 6 & 98.81 & 98.70 & 98.12 \\
\hline 7 & 164.54 & 164.23 & 162.85 \\
\hline 8 & 93.71 & 93.53 & 93.30 \\
\hline 9 & 156.42 & 156.34 & 156.28 \\
\hline 10 & 103.87 & 103.96 & 104.00 \\
\hline 1 & 120.90 & 121.15 & 121.35 \\
\hline 2 & 130.89 & 115.22 & 114.97 \\
\hline 3 & 115.12 & 144.84 & 144.77 \\
\hline 4 & 159.97 & 148.49 & 147.48 \\
\hline 5 & 115.12 & 116.21 & 116.97 \\
\hline 6 & 130.89 & 121.62 & 121.49 \\
\hline $1^{\prime \prime}$ & 100.87 & 100.85 & 100.80 \\
\hline $2^{\prime \prime}$ & 74.22 & 74.01 & 73.13 \\
\hline 3 & 76.41 & 76.51 & 76.20 \\
\hline 4 & 69.89 & 69.94 & 69.63 \\
\hline $5^{\prime \prime}$ & 77.51 & 77.60 & 75.32 \\
\hline $6^{\prime \prime}$ & 60.83 & 60.98 & 66.12 \\
\hline $1^{\prime \prime}$ & & & 100.31 \\
\hline $2^{\prime \prime}$ & & & 70.99 \\
\hline $3 \cdots$ & & & 71.10 \\
\hline $4^{\prime \prime}$ & & & 71.38 \\
\hline $5^{\prime \prime}$ & & & 67.87 \\
\hline $6 "$ & & & 17.02 \\
\hline
\end{tabular}

Spectra measured by $75^{*}$ and $100^{* *} \mathrm{MHz}$, (DMSO$d_{6}$ ), relative to TMS).

Isorhamnetin-3-O-rutinoside (7): Yellow amorphous powder $(50 \mathrm{mg}), \mathrm{R}_{\mathrm{f}}=0.46$ (system II), UV $\left(\lambda_{\max } \mathrm{nm}\right) \mathrm{MeOH}: 254,309 \mathrm{sh}, 355$, NaOMe: $265,320 \mathrm{sh}, 405, \mathrm{AlCl}_{3}: 264,356 \mathrm{sh}$, 405, $\mathrm{AlCl}_{3} / \mathrm{HCl}: 264,354,402, \mathrm{NaOAc:} 272$, $295,377, \mathrm{NaOAc} / \mathrm{H}_{3} \mathrm{BO}_{3}: 254,295,358 .{ }^{1} \mathrm{H}-$ NMR spectrum (300 MHz, $\mathrm{CD}_{3} \mathrm{OD}$ ): $\delta 3.20-$ $3.60(\mathrm{~m}$, sugar protons $), 4.47(1 \mathrm{H}, \mathrm{d}, \mathrm{J}=2.00$ $\mathrm{Hz}, \mathrm{H}-1^{\prime \prime \prime}$, anomeric proton of rhamnose), 5.00 $\left(1 \mathrm{H}, \mathrm{d}, \mathrm{J}=7.50 \mathrm{~Hz}, \mathrm{H}-\mathrm{1}^{\prime \prime}\right.$, anomeric proton of glucose $), 1.13\left(3 \mathrm{H}, \mathrm{d}, \mathrm{J}=6.50 \mathrm{~Hz}, \mathrm{CH}_{3^{-}}\right.$ rhamnose), $3.86\left(3 \mathrm{H}, \mathrm{s}, \mathrm{OCH}_{3}\right), 5.95(1 \mathrm{H}, \mathrm{d}, \mathrm{J}=$ $2.00 \mathrm{~Hz}, \mathrm{H}-6), 6.09(1 \mathrm{H}, \mathrm{d}, \mathrm{J}=2.50 \mathrm{~Hz}, \mathrm{H}-8)$, $6.67\left(1 \mathrm{H}, \mathrm{d}, \mathrm{J}=8.50 \mathrm{~Hz}, \mathrm{H}-5^{\prime}\right), 7.58(1 \mathrm{H}, \mathrm{dd}, \mathrm{J}=$ $\left.2.50,8.50 \mathrm{~Hz}, \mathrm{H}-6^{\prime}\right), 7.88(1 \mathrm{H}, \mathrm{d}, \mathrm{J}=2.50 \mathrm{~Hz}$, $\left.\mathrm{H}-2^{\prime}\right)$.
Quercetin-3-O-rutinoside (8): Yellow amorphous powder $\left(50 \mathrm{mg}\right.$ ), $\mathrm{R}_{\mathrm{f}}=0.30$ (system II), UV ( $\left.\lambda_{\max } \mathrm{nm}\right) \mathrm{MeOH}: 259,266 \mathrm{sh}, 299 \mathrm{sh}$, 359, NaOMe: 272, 325, 410, $\mathrm{AlCl}_{3}: 275$, 303sh, 430, $\mathrm{AlCl}_{3} / \mathrm{HCl}: 271,300,364 \mathrm{sh}, 402$, NaOAc: 271, 325, 390, $\mathrm{NaOAc} / \mathrm{H}_{3} \mathrm{BO}_{3}: 262$, 298, 387. ${ }^{1} \mathrm{H}-\mathrm{NMR}$ spectrum $(400 \mathrm{MHz}$, DMSO- $\left.d_{6}\right): \delta 3.06-3.70$ (m, sugar protons), $5.32\left(1 \mathrm{H}, \mathrm{d}, \mathrm{J}=7.1 \mathrm{~Hz}, \mathrm{H}-1^{\prime \prime}\right.$, anomeric proton of glucose $), 4.37\left(1 \mathrm{H}, \mathrm{d}, \mathrm{J}=1.5 \mathrm{~Hz}, \mathrm{H}-1^{\prime \prime \prime}\right.$, anomeric proton of rhamnose), $1.03(3 \mathrm{H}, \mathrm{d}, \mathrm{J}=$ $6.32 \mathrm{~Hz}, \mathrm{CH}_{3}$-rhamnose $), 6.17(1 \mathrm{H}, \mathrm{d}, \mathrm{J}=2.20$ $\mathrm{Hz}, \mathrm{H}-6), 6.37(1 \mathrm{H}, \mathrm{d}, \mathrm{J}=2.20 \mathrm{~Hz}, \mathrm{H}-8), 6.82$ $\left(1 \mathrm{H}, \mathrm{d}, \mathrm{J}=8.00 \mathrm{~Hz}, \mathrm{H}-5^{\prime}\right), 7.52(1 \mathrm{H}, \mathrm{d}, \mathrm{J}=2.20$ $\left.\mathrm{Hz}, \mathrm{H}-2^{\prime}\right), 7.67(1 \mathrm{H}, \mathrm{dd}, \mathrm{J}=2.20,8.00 \mathrm{~Hz}, \mathrm{H}-$ $\left.6^{\prime}\right), 12.53(1 \mathrm{H}, \mathrm{s}, 5-\mathrm{OH}),{ }^{13} \mathrm{C}-\mathrm{NMR}$ spectrum (100 MHz, DMSO- $d_{6}$ ): Table 2.

\section{RESULTS AND DISCUSSION}

Repeated ODS column chromatography and sephdex LH-20 of ethyl acetate soluble fraction of the methanolic extract of the stem bark of Acer negundo (L.) afforded compounds 1, 2, 5 and $\mathbf{6}$ which gave dark blue colour with ferric chloride reagent.

Compound $\mathbf{1}$ was identified as gallic acid by comparing its physico-chemical data such as m.p, IR and co-TLC with reference sample.

${ }^{1} \mathrm{H}-\mathrm{NMR}$ spectra of compounds 5 and $\mathbf{6}$ displayed two singlet signals at $\delta 7.03$ and 7.20 , each for two aromatic protons $(\mathrm{H}-2,6)$. The spectrum of compound $\mathbf{5}$ showed a singlet signal at $\delta 3.85$ assigned for a methoxyl group. The spectrum of compound $\mathbf{6}$ showed a signal at $\delta 4.25$ assigned for methylene group neighbouring to oxygen and a triplet at $\delta 1.32$ for an aliphatic methyl group which were confirmed by signals in ${ }^{13} \mathrm{C}-\mathrm{NMR}$ at $\delta 61.3$ and 14.3 respectively. Other ${ }^{13} \mathrm{C}$-NMR data were in agreement with those reported for galloyl moiety. ${ }^{15}$ From the above data, compound $\mathbf{5}$ was identified as methyl gallate and compound 6 as ethyl gallate and this is the first report for their isolation from the stem bark of Acer negundo (L.).

The FAB-MS of compound 2 showed $[\mathrm{M}+1]^{+}$at $\mathrm{m} / \mathrm{z} 485$ was consistent with the molecular formula of $\mathrm{C}_{20} \mathrm{H}_{20} \mathrm{O}_{14}$. The ${ }^{1} \mathrm{H}-\mathrm{NMR}$ spectrum of compound $\mathbf{2}$ displayed two galloyl groups at $\delta 7.12(4 \mathrm{H}$, s) and an anomeric proton at $\delta 6.04(1 \mathrm{H}, \mathrm{d}, \mathrm{J}=7.50 \mathrm{~Hz})$. The 
configuration of the glucose C-1 position was concluded to be $\beta$ on the basis of the $J$ value $(7.50 \mathrm{~Hz}) .{ }^{16}$ The downfield position of the anomeric proton at $(\delta 6.04)$ indicated that one of the two galloyl groups is located at C-1'. It showed also a triplet at relatively lowfield $(\delta$ 5.25) and this signal could be assigned for the C-2 proton from the fact that it was shown to be coupled with the anomeric proton. The ${ }^{1} \mathrm{H}$ and ${ }^{13} \mathrm{C}$-NMR spectral data were in accordance with the reported data for 1,2-di-O-galloyl- $\beta$-Dglucopyranoside ${ }^{17,18}$ which was isolated for the first time from the stem bark of Acer negundo (L.).

The UV spectral data in methanol for compounds 3, 4, 7 and 8 indicated their $\mathrm{C} 3-\mathrm{OH}$ substituted flavonol nature. ${ }^{19}{ }^{1} \mathrm{H}-\mathrm{NMR}$ spectrum of compound $\mathbf{3}$ displayed two doublets of meta-coupled protons of ring $\mathrm{A}$ at $\delta$ 6.20 and $6.42(\mathrm{~J}=1.80 \mathrm{~Hz})$ for $\mathrm{H}-6$ and H-8. It showed also two doublets at $\delta 6.88$ and 8.04 $(\mathrm{J}=9.00 \mathrm{~Hz})$ for $\mathrm{H}-3^{\prime}, 5^{\prime}$ and $\mathrm{H}-2{ }^{\prime}, 6$ respectively. These data suggested a kaempferol skeleton with an anomeric glucose proton with $\beta$-configuration ${ }^{16}(\mathrm{~J}=6.90 \mathrm{~Hz})$ at $\delta$ 5.46. Acid hydrolysis of compound 3 yielded sugar part identified as glucose (system IV) and kaempferol aglycone. From the UV data with different ionising and complexing agents, ${ }^{19}$ the sugar attachement was assigned to be at C-3. ${ }^{13} \mathrm{C}-\mathrm{NMR}$ data showed good agreement with those reported for kaempferol-3-O- $\beta$-Dglucopyranoside. $^{20}$

${ }^{1} \mathrm{H}-\mathrm{NMR}$ spectrum of compound $\mathbf{7}$ showed three aromatic protons of ring $\mathrm{B}$ which was confirmed through an ABX-type coupling at $\delta$ $7.58\left(1 \mathrm{H}, \mathrm{dd}, \mathrm{J}=2.50,8.50 \mathrm{~Hz}, \mathrm{H}-6{ }^{`}\right), 6.67(1 \mathrm{H}$, $\left.\mathrm{d}, \mathrm{J}=8.50 \mathrm{~Hz}, \mathrm{H}-5^{\prime}\right)$ and $7.88(1 \mathrm{H}, \mathrm{d}, \mathrm{J}=2.0$ $\left.\mathrm{Hz}, \mathrm{H}-2^{\prime}\right)$, in addition, two doublets with $\mathrm{J}=$ $2.50 \mathrm{~Hz}$ at $\delta 5.95$ and 6.09 assigned for $\mathrm{H}-6$ and H-8 respectively. The spectrum showed also a singlet signal at $\delta 3.86$ assigned to a methoxyl group, a doublet signal at $\delta 1.13(\mathrm{~J}=6.5 \mathrm{~Hz})$ for $\mathrm{CH}_{3}$-rhamnose and two doublets at $\delta 4.47(\mathrm{~J}=$ $2.00 \mathrm{~Hz})$ and at $5.00(\mathrm{~J}=7.5 \mathrm{~Hz})$ for the anomeric protons of rhamnose and glucose respectively. From studying the effect of ionizing and complexing agents, acid hydrolysis followed by co-TLC for each of the sugar part and the aglycone as well as comparing its ${ }^{1} \mathrm{H}-\mathrm{NMR}$ data with those reported, ${ }^{21}$ it could be concluded that compound 7 was identified as isorhamnetin-3-
O-rutinoside which was isolated from the leaves of the studied plant. ${ }^{14}$

The ${ }^{1} \mathrm{H}-\mathrm{NMR}$ spectra of compounds $\mathbf{4}$ and 8 showed two doublets with meta coupling at $\delta$ $6.18,6.17$ for $\mathrm{H}-6$ and at $\delta 6.39,6.37$ for $\mathrm{H}-8$ respectively. The spectra showed also three aromatic protons of ABX-type coupling, two doublets at $\delta 6.83,6.82$ for ${\mathrm{H}-5^{\prime}}^{\prime}$, at $\delta 7.51,7.52$ for H-2' and a doublet of doublet at $\delta 7.65,7.67$ for $\mathrm{H}-6^{\prime}$. The presence of sugar was confirmed by the appearance of one anomeric proton at $\delta$ $5.46(1 \mathrm{H}, \mathrm{d}, \mathrm{J}=7.20 \mathrm{~Hz})$ in 4 characteristic for glucose and two anomeric protons at $\delta 4.37$ $(1 \mathrm{H}, \mathrm{d}, \mathrm{J}=1.50 \mathrm{~Hz})$ and at $5.32(1 \mathrm{H}, \mathrm{d}, \mathrm{J}=7.10$ $\mathrm{Hz}$ ) characteristic for rhamnose and glucose in 8. Rhamnose was also confirmed by the presence of methyl signal at $1.03(3 \mathrm{H}, \mathrm{d}, \mathrm{J}=$ $6.32 \mathrm{~Hz}$ ) and at $\delta 17.02$ in ${ }^{13} \mathrm{C}-\mathrm{NMR}$, Table 2. Acid hydrolysis of each of compounds $\mathbf{4}$ and 8 followed by co-TLC with authentic samples revealed the presence of glucose in $\mathbf{4}$, glucose and rhamnose in $\mathbf{8}$. From the aforementioned studies as well as comparison with reported data, ${ }^{20}$ it could be concluded that compounds 4 and 8 were quercetin-3-O- $\beta$-D-glucopyranoside and quercetin-3-O-rutinoside respectively which were isolated for the first time from the stem bark of the studied plant.

\section{Acknowledgment}

The author wishes to express her thanks to Dr. Hamdy M. Abdel Rahman, Department of Medicinal Chemistry, Kyoto Pharmaceutical University, Kyoto, Japan for carrying out the ${ }^{1} \mathrm{H}$ - and ${ }^{13} \mathrm{C}-\mathrm{NMR}$.

\section{REFERENCES}

1- M. A. Dirr, M. Stephan, A. Sadauskas, N. Snyder and B. Dirr, "Manual of Woody Landscape Plants": Their Identification, Ornamental Characteristics, Culture, Propagation and Uses, $3^{\text {rd }}$ Edn. Stipes Publishing Co., Champain, pp. 35-71 (1983).

2- L. H. Bailey, "The Standard Cyclopedia of Horticulture", $1^{\text {st }}$ Edn., Vol. I, The MacMillan Company, New York, pp. 4950 (1963).

3- K. R. Kirtiker and B. D. Basu, "Indian Medicinal Plants, vol. I, $2^{\text {nd }}$ Edn, M/S Bishen Singh, Mahendra Pal Singh, M/S Periodical Experts, p. 639 (1975). 
4- S. Nagumo, N. Kaji, T. Inoue and $M$. Nagai, Chem. Pharm. Bull., 41 (7), 12551257 (1993).

5- T. Fossen and M. Andersen, Phytochemistry, 52 (8), 1697-1700 (1999).

6- S. Baoji, N. Saito, M. Yokoi, A. Shigihara and T. Honda, Phytochemistry, 31 (2), 655-657 (1992).

7- M. M. Abou-Zaid and C. Nozzolillo, Phytochemistry, 52, 1629-1631 (1999).

8- M. Nagai, N. Kenmochi, M. Fujita, N. Furukawa and T. Inoue, Chem. Pharm. Bull., 34 (3), 1056-1060 (1986).

9- N. Seiji, I. Sumiko, N. Masahiro and T. Inoue, Chem. Pharm. Bull., 44 (5), 10861089 (1996).

10- N. Parveen, N. Khan, T. Inoue and M. Sakurai, Phytochemistry, 27 (12), 39903991 (1988).

11- H. J. Kim, E. R. Woo, C. G. Shin and H. Park, J. Nat. Prod., 61, 145-148 (1998).

12- T. Inoue, Y. Ishidate, M. Fujita, M. Kubo and M. Fukushima, J. Pharm. Soc., Japan, 98, 41-46 (1978).
13- A. E. Bailey, R. O. Asplund and M. S. Ali, J. Nat. Prod., 49, 1149-1150 (1986).

14- E. Y. Backheet, Bull. Pharm. Sci., Assiut University, 24 (1), 1-6 (2001).

15- G. Nonaka, H. Nishimura and I. Nishioka, Chem. Pharm. Bull., 30 (6), 2061-2067 (1982).

16- J. B. Harborn, "The Flavonoids, Advances in Research Since 1986", Champan and Hall, Glasgow, New York, Tokyo, Melbourne, Madras, (1994).

17- Y. Kashiwada, G. Nonaka, I. Nishioka and T. Yamagishi, Phytochemistry, 27 (5), 1437-1477 (1988).

18- S. H. Lee, T. Tanaka, G. Nonaka and I. Nishioka, Phytochemistry, 28 (12), 34693472 (1989).

19- T. J. Mabry, K. R. Markham and M. B. Thomas, "The Systematic Identification of Flavonoids", Springer-Verlag, New York, Heidelberg, Berlin (1970).

20- P. K. Agrawal, "Carbon-13 NMR of Flavonoids", Elsevier, Amsterdam, Oxford, New York, Tokyo, 1989.

21- N. Chaurasia and M. Wichtl, Planta Med., 53, 432 (1987). 